\title{
Tax Amnesties in Indonesia and Other Countries: Opportunities and Challenges
}

\author{
Mokhamad Khoirul Huda ${ }^{1} \&$ Agus Yudha Hernoko $^{2}$ \\ ${ }^{1}$ Faculty of Law, Hang Tuah University, Surabaya, Indonesia \\ ${ }^{2}$ Faculty of Law, Airlangga University, Surabaya, Indonesia \\ Correspondence: Mokhamad Khoirul Huda, Faculty of Law, Hang Tuah University, Jalan Arif Rahman Hakim No. \\ 150 Surabaya 60111, Indonesia. Tel: 62-813-5743-7000. E-mail: emka.huda@hangtuah.ac.id
}

Received: March 26, 2017

doi:10.5539/ass.v13n7p52
Accepted: May 23, 2017 Online Published: June 23, 2017

URL: https://doi.org/10.5539/ass.v13n7p52

\begin{abstract}
Recently, revenue of national budget from taxes has decreased since economic deceleration happened and many capitals and assets of Indonesian people were stationed overseas. In order to encourage the economic growth, the government establishes regulations on tax amnesty. This paper primarily aims to find out the implementation of tax amnesty in Indonesia which had run three times since 1964, 1984, and 2016; and to compare it with similar program implemented by several countries such as South Africa, India, and Italy. Tax amnesty program in 1964 and 1984 was considered unsuccessful due to the political condition at that moment and the government indifference to socialize this matter to the taxpayers. However, it differs from South Africa, India, and Italy which are considered successful in implementing the tax amnesty program, because it brings good impact on their national revenue and increased the obedience of the taxpayers. In order to reach the objectives of the tax amnesty program in 2016, Indonesia government needs to revise the regulations of taxation, prepare the human resource of tax officers, to prepare information system related to the data of taxpayers, to improve the coordination of public agencies from Financial Service Authority and Indonesian Financial Transaction Reports and Analysis Center (INTRAC) and to enforce the regulation after the enactment of tax amnesty.
\end{abstract}

Keywords: tax amnesty, taxpayer, penal, government, ransom

\section{Introduction}

National development constantly and sustainably aims to improve people's material and spiritual welfare. The goal of national development is stated in the 1945 Constitution at the fourth paragraph, that is: "to promote the general welfare ...” In order to reach that goal, it needs adequate sources of development funds.

Seeking the national revenue in tax sector needs real efforts implemented through public policies. Such efforts could be in the form of both intensification and extensification of taxation. Tax intensification could be in the form of increasing the number of taxpayers or increasing the amount of tax revenue itself. Attempting intensification could be in the form of expanding the tax object unregistered yet. Whereas, tax extensification could be in the form of expanding tax subject or object by taking back the existing funds stationed overseas with an expectation that there would be increasing revenue from tax sector.

Tax is one dominant source of revenue for national budget. In national budget policy in 2016, the government determined the target of national revenue, $\mathrm{Rp} 1.822,5$ trillion and $75 \%$ of them that is $\mathrm{Rp} 1.546,7$ trillion is from tax (www.kemenkeu.go.id). The target of revenue and the tax sector are relatively much more than the target of national budget in 2015 that was Rp 1.489,3 trillion with 83\% of them, Rp 1.235,8 trillion, was from tax (Haryanto, 2016).

However, national economic growth has recently tended to decelerate which impacts on declining tax revenue and the stock of domestic liquidity needed to improve the economic growth of Indonesia. On the other hand, the amount of Indonesian capital and asset kept in overseas are supposed to be useful for increasing the domestic liquidity in order to encourage national economic growth.

Document divulgence known as "the Panama Papers" mentions about 800 names of Indonesian businessmen and politician listed as clients of Mossack Fonseca. It shows an action of diverting capital of assets in order to evade taxation liabilities. Indonesian's capital and assets are diverted to countries with lower taxation rate or even free 
rate (tax heaven country). The most favorable countries for capital and assets diversion are Virgin Islands, Great Britain, Cook Island, Delaware (Texas), and Singapore. It is about 2.040 of 2.580 Indonesian people who keep their capital in tax heaven country. The amount of the money diverted to tax heaven country reaches $\mathrm{Rp} 11.500$ trillion or much more than Indonesia gross domestic product in 2015 which reached Rp 11.400 trillion (Rasbin, 2016). Whereas, Indonesian's capital diverted to Singapore is about Rp 3000 trillion (Prasetyo, 2016).

Particular actions are needed to encourage capital and assets diversion to Indonesia and simultaneously provide a security guarantee for Indonesian people diverting or reporting their capital and assets in the term of tax amnesty. Breaking through in policy with tax amnesty of capital and assets diversion is driven by the decreasing possibility to conceal assets and capital into other countries and the more transparency in global finance. It is strengthened by the increasing intensity of information exchange among countries after they have signed an agreement of automatic exchange system of information in G20 summit and it will be applied by 2018.

The policy of tax amnesty is implemented in the form of state abolition to collect taxes that should be payable, even the criminal and administrative penalties. Therefore, it is granted that taxpayers must pay the ransom of tax amnesty. If the program of tax amnesty had been well-run, it would obtain USS 7.6 million (Brodjonegoro, 2016).

\section{Method}

The research constitutes legal research which Black's Law Dictionary defines it as: the finding and assembling of arthritic's that bear on a question of law; and the field of study concerned with the effective marshaling of authorities that bear on the question of law (Gardner, 1999). Jurisprudence has a normative nature (Hadjon, 1997). Therefore, the jurisprudence has distinctive features (sui generis) that are first, empirical analytic, describing and analyzing the contents and legal structures; second, systematizing the symptoms of law; third, interpreting the substance of the prevailing law; and fourth, the practical meaning of law is closely related to its normative dimension.

The research method includes the approach, the determination of legal sources and critical analysis on the sources through exploration, inquiry and interpretation. The research is a normative research which refers to the legal norms contained in statutes and judicial decisions relating to the issues. This uses statute and comparative approaches (Ibrahim, 2008).

According to Black's Law Dictionary, legal sources cover such as constitution, treaty, statute, or custom that provides authorities-for legislation and judicial decisions; a point of origin of the law or at analysis. In the context of legal research, the term "sources of law" can refer to three rent concepts which should be distinguished. One, sources of law can refer to the origin of legal concepts and ideas; two, sources of law can refer to governmental institutions that formulate legal rules; three, sources of law can refer to the published manifestations of the law. The books, computer databases, forms, optical disks, other media that contain legal information are all of law (Gardner, 1999).

Steps of collecting sources of law include reading, learning, quoting, comparing and connecting the sources of law and literatures, so that they become a unity to make easy in processing. The collected legal sources are managed by first, editing, namely checking sources of law carefully to avoid errors of sources of law; second, classifying the collected legal sources according to subject; and third, organizing them according to the groups to avoid mistakes and to be as the systematization of sources.

The sources of law are then analyzed in accordance with the classification of problems. The analysis is conducted and written in the form of describing, analyzing, systemizing, interpreting and evaluating them. The next step is that they are theoretically analyzed to find, understand and explain in depth the tax amnesty in Indonesia.

\section{Discussion}

\subsection{The Conceptual Meaning of Tax Amnesty}

The term 'amnesty' is literally derived from Greek 'amnestia' defined as 'forgetting or an act of forgetting'. Black's Law Dictionary defines amnesty as a pardon extended by the government to a group or class of persons. It is a legal forgiveness from certain infractions (Gardner, 1999). Furthermore, The Oxford dictionary defines tax as a compulsory contribution to support the government to carry out public services. It is levied on persons, properties, incomes, commodities, and transactions at a fixed rate mostly proportionate to the amount on which the contribution is levied (Josephine, 2015).

Amnesty is the President's right as stipulated in article 14 act (2) the 1945 Constitution. The article mentions that 
amnesty should be taking into the consideration of House of Representative. Relating to taxation, tax amnesty refers to the abolition of penalties by President in particular condition toward taxpayers who had done infringement of taxation laws. Hence, tax amnesty is providing taxation facility with abolition in particular period of time of imposition, investigation, and prosecution of wealth or income previously, whether entirely or partly, taxed due to recantation of the taxpayers who regretted and promised no longer do such infringement.

Jacues Malherbe defines tax amnesty as "the possibility of paying taxes in exchange for the forgiveness of the amount of tax liability including interest and penalties, the waiver of criminal tax prosecution and/or limitations to audit tax determinations for a period of time.” Whereas, Carla Marchese argues that it is an opportunity given to taxpayers to write off an existing tax liability (including interest and fines) by paying a defined amount. Such offers are usually presented being exceptional and available for only a limited period of time. Amnesties can either be general or restricted to certain groups of taxpayers or taxes, and the routinely include the waiving of criminal and civil penalties (Prastowo, 2016).

Tax amnesty is defined as a work of works of the legislature authority, which aimed to delete an offense criminal and, thus, to prevent or stop prosecutions or clear condemnation (Chatagny, 2008). On the other hand, Od Heige Fjeidstad states that tax amnesty is a rule or law issued by the government to forgive tax debts of previous years to taxpayers. Through this measure, the government provides a benefit to taxpayers by allowing them to rectify mistake or omissions in tax returns without any rear of legal actions. In other words, Government sacrificed the penalties by passing non-compliance in exchange for improving compliance in the future. The amnesty is usually established for a fixed period time. Two potential rationales for introducing tax amnesties: the first is the idea that a state would initiate a tax amnesty if it expected the amnesty program to produce a significant revenue yield; and the second is the idea that a state would introduce an amnesty in times of fiscal duress, thus, the amnesty is one source for increasing revenue collection during a recessionary period (Borgne, 2006).

Tax amnesty aims to: (a) rapidly obtain the revenue; (b) improve the level of obedience by taxpayers; (c) distance from previous government; (d) mark the change of regime; and/or (e) repatriate assets kept overseas; (f) collect the real data of taxpayers which could be a base to improve law enforcement and tax revenue (Prasetyo, 2016).

However, the establishment of tax amnesty also brings several risks up, such as: (a) in a long term, taxpayers who had been honest for so long were likely to be dishonest after the establishment of tax amnesty since they expected another tax amnesty in the future; (b) indicating a possibility and facility for tax evasion; (c) obedient taxpayers often assumed tax amnesty as an injustice; and (d) providing tax amnesty might decrease the obedience of taxpayers precisely since they believed that further tax amnesty would be established without any better law enforcement.

\subsection{Implementation of Tax Amnesty in Indonesia}

Before finally establishing tax amnesty, the government needs to consider the overall level of obedience by a taxpayer, including the quality, and conduct some efforts in order to reinforce taxation laws. Primarily on which considering tax amnesty, the government has to predetermine precisely the problem which lead taxation system into such condition requiring the policy to be implemented.

Taxpayers will recognize that the problem of the tax system has not been solved and that since these problem have resulted in the amnesty once, they are likely to do so again (Alm, 1998).

In Indonesia, the policy of tax amnesty had been implemented three times and be considered unsuccessful. The following would address the condition.

\subsubsection{Tax Amnesty in 1964}

Tax regulation in 1964 was under the enactment of articles 16, 17, and 19, Indische Compatibilities Wet (ICW) April 23 ${ }^{\text {th }}$, 1864, stbl. 1864 No.106. Stbl. 1925 No. 448 which had been amended in L.N. 1954 No. 6 ; 1955 No. 49 and finally under the enactment No. 9 of 1968. Article 16 mentioned that regulation on procurement of new taxes, raising or declining or abolishing existing taxes or rescission of the source of revenue was not allowed until it was revealed in budget of revenue. Article 17 mentioned that tax refund or tax abolition was allowed only in cases and with means prescribed by the general rule. Whereas, article 19 mentioned that Government granted billing acquittance only if the amount of the acquaintance reached over Rp 10.000,- in which the acquittance was under the governmental regulation that gave a grant only after considering advices from Audit Board.

The policy of tax amnesty was first conducted by Government in 1964 by establishing the Presidential Decree No. 5 of 1964 on the regulation of tax amnesty, dated on $9^{\text {th }}$ September, 1964, gazette No. 89 and additional gazette No. 2677 of 1964. Based on Indische Compatibilities Wet (ICW), tax amnesty conducted by Government 
through the Presidential Decree was appropriate. It was due to the House of Representatives, as a mandate of the 1945 Constitution, had not been held yet. Hence, the Presidential Decree was based on article IV Transitional Rules.

The policy of such amnesty was based on a consideration of the needs to address national interest and national entire development in general and to facilitate the implementation of Economic Declaration dated on March $28^{\text {th }}$, 1963, and mobilize all funds, efforts, and power in particular.

Article 1 act (1) mentions, "People's capital which has not been yet taxed on behalf of corporate, income and property taxes, and which has been registered to Directorate of Tax before August $17^{\text {th }}$, 1965 cannot be accepted as motive for public agencies in fiscal or criminal to conduct a inquiry, investigation, and inspection dealing with its origin".

The Presidential Decree No. 5, 1964 on article 1 act (2) mentions the imposition of ransom with two kinds of provision as follow.

a. Rate $5 \%$ is charged if the capital of a taxpayer on which asking an amnesty has been or is being invested in agriculture, fishery, ranch, mining, manufacture and transportation sectors prescribed by Minister of Revenue, Budgeting, and supervision.

b. Rate $10 \%$ is charged on taxpayer's capital/assets on which asking an amnesty has not been yet taxed, and is being invested in other sectors not prescribed by Minister.

Article 3 act (1) mentions, "if in fact, due to incorrectness and incompleteness of intended liability, the ransom had been remitted is less than what it should be pay, additional payment should be conducted as much the amount had not been pay, added by $400 \%$ as charge as long as it has not been overdue, since August $17^{\text {th }}, 1965$, by 2 (two) years."

Article 6 act (1) mentions, "whoever intentionally, on the due date predetermined at article 1 act (1), do not do intended liabilities, will be sentenced with confinement for maximally 5 (five) years or fined penalty at most 100 (one hundred) million rupiahs. The evidence, in article 3, was considered as disobedience, whereas, in article 6 , act (1), was considered as crime.

Kinds of taxes covered by tax amnesty are corporate taxes, income taxes, and property taxes. Tax amnesty was granted considering the revenue and capital accumulation received before November $10^{\text {th }}$, 1964 which has not been yet reported in tax return and which has not been yet taxed on behalf of whether income, corporate, or property taxes. The tax relief provided by Government was in the form of tax amnesty or incentives. Tax amnesty, at that moment, did not question on the sources of revenue, whether or not it was derived from corruption, bribe, or untold tax embezzlement.

The Presidential Decree had regulated the duration time period of implementing tax amnesty which was for 344 days since September $9^{\text {th }}, 1964$ up to August $17^{\text {th }}, 1965$. Tax amnesty implemented in 1964 aimed to get funds of revolution back. The failure of its implementation was due to G 30S / PKI. Besides, the historical fact showed that tax amnesty program did not have any good responses from people since it did not come along with amnesties in other sectors, and, in addition, the quality of taxation administrative system was still minimum.

\subsubsection{Tax Amnesty in 1984}

April $18^{\text {th }}$, 1984 was a momentum for the second amnesty in Indonesia. On that day, The Presidential Decree No. 26 of 1984 was established which then was amended with the Presidential Decree No. 72 of 1984 mentioning the policy of tax amnesty. The content of amendment merely dealt with the due date of submission for requesting amnesty, from originally on December $31^{\text {st }}$, 1984 became June $30^{\text {th }}, 1985$.

The policy of tax amnesty in 1984 was motivated by the change of new taxation system aiming to improve people's financial contributions for national development. Official assessment system of tax collection changed into self assessment system with policy of tax reform introduced by Government in 1983.

Besides, the establishment of the Presidential Decree No. 72 of 1984 was motivated by different potential taxes, in which that moment, was unreachable by its regulation. These potential lost taxes could be due to the fact that taxpayers did not pay their taxes at all, diverted their assets overseas by considering that the other countries' tax rate was less and etc.

Taxpayers participated or eligible to join the tax amnesty program, as mentioned in article 1 act (1) whether individual or corporate with name and any form of corporation, and whether or not had been registered as taxpayer, were allowed to get tax amnesty. 
Kinds of taxes covered by tax amnesty was regulated under article 1 act (2), tax amnesty was granted for taxes which has not fully or partly been collected under the established regulation that consists of:

a. Income tax of income obtained in 1983 taxation year and previous year

b. Property tax of assets owned since January $1^{\text {st }}, 1984$ and the previous year;

c. Corporate tax of profit obtained in 1983 taxation year and the previous year;

d. Tax of interest, dividend, and royalty of payable interest; dividend and royalty pay or provided to pay until December31 $1^{\text {st }}, 1983$;

e. Calculating other people's payable taxes even on which in 1983 and the previous year;

f. Employees income tax payable in 1983 taxation year and the previous year; and

g. Sales tax payable in 1983 and the previous year.

Of taxes which had not fully or partly been collected, they had to pay for ransom based on the following rates:

a. $1 \%$ (one percent) of the assets used as the basis for calculating the amount of tax for which the amnesty be granted for taxpayer who, on the due date of establishing the Presidential Decree No. 26 of 1984, had registered SPtP.Pd/P.Ps, 1983 and P.Kk, 1984; and

b. $10 \%$ (ten percents) of the assets used as the basis of calculating the amount of tax for which amnesty be granted for taxpayer who, on the due date of establishing the Presidential Decree No. 26 of 1984, had not registered SPtP.Pd/P.Ps, 1983 and P.Kk, 1984.

(article 3 act (1)).

Article 7 act (1) mentioned that taxpayer was released from fiscal investigation. This provision indicated that if taxpayers made report to get tax amnesty, they would not be investigated in fiscal, implying that tax payable which had not been fully or partly collected before 1984 would not be charged to pay or would not be collected by tax officers. On the other hand, act (2) regulated report on assets so that tax amnesty would not be used as the base of investigation and criminal prosecution in any form toward the taxpayer. The period of implementing this second tax amnesty started on April $18^{\text {th }}$, 1984 till June $30^{\text {th }}, 1985$.

The implementation of tax amnesty in 1984 was considered not effective since the tax payers did not give any good response and entirely reformation of taxation administrative system did not occur afterward. In addition, it was also due to the minimum transparency and improvement of information access toward people including the controlling system by Directorate General of Tax itself.

Besides, tax contribution on state budget system merely remained as complement of which the government did not do any serious effort. At that moment, national revenue was dominated by oil and gas export. Whereas, tax revenue, recently, became a dominant source in national budget system.

\subsubsection{Tax Amnesty in 2016}

The motive of establishing the policy of tax amnesty, in this three time, dealt with the importance of people's contribution for national development by optimizing all existing resources of which was from tax. People awareness and obedience to do their tax liabilities still needed to be improved since the assets, both inbound and outbound, were not fully reported in income tax return. In order to improve the national revenue, the economic growth, people's awareness and obedience in tax implementation, it needed to establish the policy of tax amnesty.

The Act No. 11 of 2016 on tax amnesty was officially established on July 1 ${ }^{\text {st }}, 2016$ (Gazetted in 2016 No. 131 and additional gazetted No. 5899). The objectives of tax amnesty were as follow.

a. To accelerate the growth and restructuring of economic through assets diversion which would impact on the increasing of domestic liquidity, the improvement of rupiah exchange rate, the declining of interest rate, and the increasing of investment;

b. To encourage taxation reformation into more equitable tax system and the more valid, comprehensive, and integrated taxation data base extensification; and

c. To increase the tax revenue, which would be useful for national development

The regulation of tax amnesty had mentioned: the subject, object, rate, the technique of calculating the ransom, the procedures of waiver reporting, the establishment of certificate, and the amnesty of tax liability, investment obligation of revealed property, criminal penalty and report for all ministers, vise-ministers, staffs in ministry of 
finance, and other parties who had divulged, spread out, notified data and information they knew or told by taxpayers to other parties.

Taxpayers participated or eligible to join the tax amnesty program were individual or corporate with rights and obligation of tax based on the enactment of laws on taxation. The exceptional taxpayers were as follow.

a. Taxpayers who were being investigated and the document of the investigation had been complete confirmed by judiciary; and

b. Taxpayers who were in the process of jurisdiction or taxpayers who were in criminal charge due to the taxation crime.

Kinds of taxes covered by tax amnesty were income tax and value added tax, and sales tax of expensive goods. Potential repatriation fund with the establishment of tax amnesty would impact on funds belonged to Indonesian citizens stationed overseas which could be withdrawn to Indonesia; hence, it could be useful for the country. McKinsey's research on calculating the potential of national revenue derived from tax amnesty forecasted that the amount of assets diverted overseas which tax amnesty could repatriate was Rp 2.000 trillion; with assumption, rate $3 \%$ of the "ransom", it was assumed that this policy of tax amnesty could give extra revenue of tax at least Rp 60 trillion as the contribution and the implementation of this policy would be a base line of taxes in 2017, and so on. One thing to be sure that the potential revenue would be much more increasing (Prastowo, 2016).

Several facilities of tax amnesty provided for taxpayers following the program of tax amnesty were:

a. Abolishment of tax payable;

b. Abolishment of tax administrative penalty

c. Abolishment of criminal sentence in taxation; and

d. Suspended inspection, inspection of preliminary evidence, investigation of crime in taxation until the certificate of tax amnesty was established for tax period, part of tax year, or tax until March $31^{\text {st }}, 2015$, and would be stop when the minister established the certificate of amnesty.

The amount of ransom rate for assets located in Indonesia or assets located outside Indonesia which was diverted/repatriated and invested in Indonesia for 3 (three) years long counted from the time on which it was diverted was:

a. $2 \%$ (two percents) for period of reporting waiver since the first months until the end of the third month counted from the time on which this regulation was established;

b. $3 \%$ (three percents) for period of reporting waiver on the fourth month counted from the time on which this regulation was established until December $31^{\text {st }}$, 2016; and

c. $5 \%$ (five percents) for period of reporting waiver counted from the time January $1^{\text {st }}$, 2017 until March $31^{\text {st }}$, 2017.

The amount of ransom rate of assets diverted outside Indonesia and which was not repatriated to Indonesia was:

a. $4 \%$ (four percents) for period of reporting waiver since the first month until the end of the third month counted from the time on which this regulation was established;

b. $6 \%$ (six percents) for period of reporting waiver on the forth month counted from the time on which this regulation was established until December 31 $1^{\text {st }}$, 2016; and

c. $10 \%$ (ten percents) for period of reporting waiver counted from the time January $1^{\text {st }}$, 2017 until March $31^{\text {st }}$, 2107.

The amount of ransom rate for taxpayers which amount of business distribution was Rp. 4.800.000.000,00 (four million eight hundreds rupiahs) at the latter tax year was:

a. $0.5 \%$ (zero point five percent) for taxpayers reporting the amount of their properties up to Rp.10.000.000.000,00 (ten million rupiahs) in their waiver; or

b. $2 \%$ (two percents) for taxpayers reporting the amount of their properties more than Rp. 10.000.000.000,00 (ten million rupiahs) in their waiver.

In case the period in implementing tax amnesty was between July $1^{\text {st }}, 2016$ and March $31^{\text {st }}$, 2017. The provision of regulation on tax amnesty mentioned that everyone contributed to keep the confidentiality and di not divulge, spread out, and/or notify data and information they knew or were told by taxpayer to other parties would be 
sentenced with confinement for maximally 5 (five) years.

The regulation of tax amnesty had provided reward for taxpayers contributing and reporting their capital and assets, however, the punishment for taxpayers who were not willing to declare their capital and assets was not set. This became the government's limitation; hence, the reward and punishment were lame. This tax amnesty was so different from which in 1964.

\subsubsection{After Tax Amnesties}

Tax amnesty was used as a means of governmental policy mentioned in the form regulation. After establishing tax amnesty, Directorate of General Tax needed to do some steps in order to improve the level of obedience which included: the improvement of services for taxpayers by revising several regulations such as the enactment of General Tax Provision, income tax and value added tax, administration improvement by data collection through integrated technology and information system as a form of single identification number, moreover, Directorate of General Tax needed to improve the competence of their human resource so that they would have good integrity, professionalism, accountability and ethics.

Furthermore, it needed to improve the law enforcement of tax by conducting: coordination with public agencies including Financial Service Authority, Analysis Reporting Center of Financial Transaction dealing with data and information of banking customer, whereas, conducting coordination with Indonesian police officers and attorney general to improve the law enforcement in providing assurance for taxpayers ( Prawira, 2015).

\subsection{Tax Amnesty in Several Countries}

Government of several countries had frequently turned to tax amnesties as part of their unpaid taxes without being subject to some or all of the financial and criminal penalties that the discovery of tax evasion normally brought. Amnesties had been used repeatedly over time and across countries, regardless of their degree of economic development. Developed countries included: Australia, Austria (1982, 1993), Belgium (1984), Finland (1982, 1984), France (1982, 1986) Greece, Ireland (1988, 1993), Italy (1982, 1984, 2002), New Zealand (1988), Spain (1977), and Switzerland. Whereas, developing countries, included: Argentina (1987, 1995), Bolivia, Chile, Colombia (1987), Ecuador, India (several years), Panama (1974), Peru, Mexico, Philippines, Russian Federation (1993, 1996, 1997) and Turkey. In United States (78 Programs until 2004), almost all states (42 out of 50) offered tax amnesty of some sort. The result of International Monetary Fund in 2008 showed that the level of successfulness for tax amnesty in both developed and developing country was only 50\% (Prastowo, 2016). Some countries which were successful in implementing tax amnesty were as follow.

\subsubsection{South Africa}

South Africa had implemented tax amnesty program three times which was in 1995, 1995, and 2003. Essentially, many South Africans had already saved their capital or assets overseas with various motives. It was not only to avoid the exchange control regulation, but also to avoid the difficulty of revealing sources obtained inside and outside country. The taxing level of revenue obtained overseas in the past was high. Given the interest obtained from the bank account and the ownership of property overseas had to be taxed.

South Africa, in 1997, provided additional form for foreign passive income taxed toward their people. The revenue of interest and royalty were the instance. This, then, was established to all South Africans since January $1^{\text {st }}, 2001$.

In 2003, special amnesty was established which scope was limited on the admission of taxpayer's assets saved overseas, as well as the transactions dealing with the transgression of foreign exchange line. In other word, this amnesty was only limited on parties with assets saved overseas but had not been taxed yet.

The primary objectives of tax amnesty in South Africa were as follow.

a. To broaden the tax base and increase future revenue collection through disclosure of both authorized and unauthorized foreign assets;

b. To enable South Africans to regularize their affair without being prosecuted in terms of current exchange control regulations and tax laws;

c. To provide the reserve bank and the revenue service with details of foreign assets; and

d. To facilitate repatriation of South Africans' foreign assets without any fear of prosecution.

The benefits of tax amnesty in South Africa were as follow.

a. Exchange control from all civil penalties and criminal liabilities stemming from the shift of funds offshore in contravention of exchange controls on or before February $28^{\text {th }}, 2002$. 
b. Income tax abolishment from all income taxes, interest, civil and criminal penalties stemming from the failure to disclose gross income or capital gains from foreign sources if that income or capital gain arose on or before February $28^{\text {th }}$, 2002. (Prastowo, 2016).

The ownership of foreign assets derived from illegal activities or other crimes such as corruption, crime, drugs transaction, or money laundry were not allowed to get tax amnesty. Especially for inbound assets derived from domestic income and which tax had not been reported or pay would not get any facility of tax amnesty releasing fine up to $200 \%$, moreover, they would not get any looseness of liability installments. In this tax amnesty, kinds of taxes covered were merely on individual income tax, including estate duty.

The government of South Africa applied "Pull and Push" strategy. It was by providing incentives to the taxpayers, so that they were interested in joining this program. One trick used was by abolishing the fine and/or payable tax interest or even low rate payment of ransom.

Whereas, 'Push' referred to giving pressure or inconvenient feeling if only taxpayers were not willing to participate. One of the strategies was by improving the quantity and quality of tax audit, strategy of selecting appropriate target for investigation, transparency of investigation result, and tentative punishment of tax crime before the amnesty was established.

Taxpayers participated or eligible to join the tax amnesty program: the amnesty concerned on individuals, trusts and private companies. Rate: 5\% unauthorized foreign assets declared and repatriated to South Africa and 10\% unauthorized foreign assets declared but retained offshore.

Any incentives provided in tax amnesty might be in the form of assets repatriated to South Africa with $50 \%$ in rate compared if the assets remained overseas, free of criminal threat, and abolishment of $20 \%$ fine for tax payable of inbound assets and its interest

The period of tax amnesty was 9 months (June $1^{\text {st }}, 2003$ up to February $29^{\text {th }}$, 2004). The result of the program was as follows: total assets saved overseas reached euro 7.8 billion, authorized assets was euro 2.4 billion, assets previously unauthorized for exchange control purpose was euro 5.4 billion and tax collection was euro 45.4 million (Prastowo, 2016).

Tax amnesty implemented in South Africa was considered successful since: first, the government had all South Africans be obedient on the regulation of Exchange Control and any taxation issues; second, the government gave the people authority on South African Revenue Services and Exchange Control Department of the South African Reserve Bank to control the national assets of South Africa saved overseas; and third, the government facilitated the repatriation of taxpayers' foreign assets and improved the future tax revenue (Muttaqim, 2013).

\subsubsection{India}

India implemented tax amnesty once in every five or six years since 1965. India's budget, in 1965, introduced a scheme which commenced on march $1^{\text {st }}, 1965$ whereby an amnesty was granted in India in respect of unaccounted "wealth" or income , provided $60 \%$ was handed over to the reserve bank by May $31^{\text {st }}$, 1965 . It was also announced that the program was to be intensified. In addition, the Minister of Home Affair had been conducting a campaign against corruption. Six months were allowed for payment of the tax and the amount collected was impressive, especially remembering that such revenue was collected with minimum technical labors by the administration. In addition to this, provision was made for settlement in case of serious disputes against tax assessment (Josephine, 2015).

In 1981, India offered a different tax amnesty. The government of India sold the obligation which due date was in 1991 with special interest reaching $2 \%$ per year. In this program, people with black money were allowed to use their money to buy the obligation without any sort of investigation questions dealing with the origin of that money. Moreover, they would be free from tax of assets deposited and tax of primary interest revenue when it had come to the due date. Approximately estimated, one with obligation would gain extra income up to $60 \%$ in 10 years. This program was unsuccessful in expanding the tax base and did not contribute in the attempt of future precise inspection (Kurniawari, 2016).

This was due to the lack of either regulation reinforcement or other structural changes in tax system. The level of participation was considered low since the people believed that the similar program would be established with much more interesting offers.

In 1997, the government of India established a tax amnesty program considered as final tax amnesty. This program allowed the people to announce their taxable assets derived from the previous year based on its gain price, not value of on-going year. 
As the result, it could reach up to Rs 100 million or about USS 2.5 million gained from 350 thousand people as individual taxpayers. This program was considered successful in raising the tax rate since it remained interesting during inflation.

During 2004 and 2003, the government of India could collect $0.07 \%$ of the asset value illegally diverted to overseas which, from black money, approximately reach USS 510 million. In 2016, the government committed to clean the black money by giving chance for parties who did tax evasion to declare their assets.

They had four months since June $1^{\text {st }}$, 2016 until September $30^{\text {th }}$, 2016 to declare their real assets. They would get an amnesty if they pay the ransom up to $45 \%$ of the asset value previously concealed. The amount of penalty and extra expense was much more than the highest rate of income tax which reached 35\% (Kurniawari, 2016).

The taxpayers participated or eligible to join the tax amnesty program were individuals and corporate, with kind of tax covered was income tax. The forms of incentives granted in tax amnesty were abolishing administrative penalty and $30 \%$ as rate taxed of the gain value. The period of implementing the tax amnesty was 214 days stated from July until December 1997.

The implementation of the tax amnesty in 1997 was considered successful due to the increasing amount of tax revenue which reached triple of the previous tax amnesty gained. This successfulness was because of the successful promotion program through media such as radio, television, advertisement board, and newspaper promoting the benefits of joining the tax amnesty program and its highlight on the improvement of law enforcement after amnesty (Muttaqim, 2013).

\subsubsection{Italy}

Since 1991 until 2014, Italy had a number of tax amnesty programs. The government granted an amnesty for taxpayers so that they could pay the tax in lower rate. Each tax amnesty program always promoted as "the last opportunity" for all taxpayers.

In order to implement the tax amnesty program without violating fiscal regulation imposed by the European Union, and put government Berlusconi general tax amnesty law which entered into force in September 2001 until $25^{\text {th }}$ May 2002, and this was the objective of the amnesty repatriating the capitals saved overseas to Italy dealing with untold activities to tax authorities in Italy (Muloud, 2015). This tax amnesty gained euro 1.74 billion equivalent to $0.1 \%$ of Gross Domestic Product in September 2001 till May 2002. Whereas, the amount of assets revealed was about euro 560 billion or 11\% of undeclared assets saved overseas (Chatagny, 2006).

Tax amnesty program in 2009 applied Scudo Fiscale system (Fiscal Shield). The subject of the tax amnesty included: individuals, partnerships and the similar, except those who were being investigated. The objects included outbound assets saved overseas and its revenue. The period of reporting was between $15^{\text {th }}$ September and $15^{\text {th }}$ December 2009, with rate $5 \%$ of the total assets. The reported assets had to be repatriated, transferred to the institution governed by brokerage house, or regulated by adding several detail information on the asset report (for certain countries which had cooperation in tax with Italy).

For tax amnesty program in 2014, the government of Italy applied voluntary disclosure system to repatriate the national revenue of their people's assets saved overseas. The taxpayers had to voluntarily report and pay their tax payable. The benefit offered was "penalty", which alleviated the amount of tax, so that it would be less than the real tax audit they needed to pay.

The disobedience of reporting income tax, value added tax, and local tax for production activities was covered in this program. However, it did not cover taxes related to inheritance, donation, or present. Mechanism for the amount of penalty for tax payable was $100 \%$ till $200 \%$ for inbound revenue and $133 \%$ till $266 \%$ for outbound revenue.

Besides tax and fine, The Italian had outbound assets that had to be reported to tax authority of Italy and submit RW form as a part of repatriation procedures. If the taxpayers did not do the repatriation as what the form mentioned, they would get punishment annually. The punishment was in the form of $3 \%$ till $15 \%$ of the asset value on which they were in shitelisted jurisdiction.

The subjects of this tax amnesty were individuals, corporate, and subject for foreign business (related to corporation), except those who were being investigated. Furthermore, the object of this tax amnesty was all assets located in Italy and outside Italy with period of reporting was between January $1^{\text {st }}$ and September $30^{\text {st }}$, 2015. The rate for all taxes and administrative punishment was the lowest rate subtracted by $25 \%$. Of it. Kinds of amnesty were for tax punishment and money laundry. Of 1288 applications per May $18^{\text {th }}$, 2015, it gained $€ 260$ million which was $€ 16$ million from income tax, and $€ 12$ million from value added tax (Prastowo, 2016). 
Until November 2015, the government of Italy revealed $€ 60$ billion undeclared assets. Of such amount, the government successfully declared $€ 3.8$ billion or equivalent to USS 4 billion (Kurniawari, 2016).

Indonesia just learned on how to implement tax amnesty from other countries' experiences such as India, South Africa, and Italy. South Africa and India were two countries which had lots of common with Indonesia since both them are developing countries and being in transition. The two countries had huge number of the rich. In addition, Indonesia also had to learn from Italy since the country had quite much informal economy and outbound assets in Indonesia.

\section{Cloncusion}

Indonesia had already implemented tax amnesty in 1964, 1984 and 2016. Tax amnesty in 1964 and 1984 were both considered unsuccessful due to the political condition at that moment and the government ignorance toward the program. These were so different from South Africa, India, and Italy which were successful in implementing the tax amnesty program.

Tax amnesty in 2016 should be successful, and to do so, the government did not only abolish the collection right toward the taxpayers but also improved the taxpayers' awareness in order to increase the revenue of national budget, increase the data of taxpayers, increase the stock of foreign exchange through foreign currency entry, open investment, create new vocation and encourage the reformation of tax bureaucracy. The government should also do concrete actions in order to increase the tax revenue by conducting census of national taxes and improve the implementation of Indonesia National Single Windows (INSW) program.

\section{References}

Agbonika, Josephine. A. A. (2015). Tax Amnesty for Delinquent Taxpayers: A Clinche in Nigeria, Global Journal of Politics and Law Research, 3(3), 105-120.

Alm, J. (1998). Tax Policy Analysis: The Introduction of a Russian Tax Amnesty. Georgia State University.

Borgne, E. L. (2006). Economic and Political of Tax Amnesty in the U.S State, IMF Working Paper.

Brodjonegoro, B. P. S. (2016). Meraih Penerimaan Melalui Pengampunan. Media Keuangan, XI(103). 23-24.

Chatagny, Florian. (2008). L’Analyse Economique des amnisties Fiscales, Travail de Master, Fribourg.

Gerner, B. A. (1999). Black’s Law Dictionary, ninth edition, London: West Thomas Reuter Publisher.

Hadjon, P. M. (1997). Pengkajian Ilmu Hukum, Makalah Penelitian Hukum Normatif. Surabaya: Universitas Airlangga.

Haryanto, J. T. (2016). Tax Amnesty dan Kinerja Perpajakan 2016, Media Keuangan, XI(103), 41-42.

Helge F., Odd. (2014). Tax Amnesty in Angola: a fresh start or a vicious circle? Angola Brief, 4(9), 1-4.

Ibrahim, J. (2008). Teori \& Metodologi Penelitian Hukum Normative. Malang: Bayu Media.

Kurniawari, I. (2016). Meraih Penerimaan Melalui Pengampunan, Media Keuangan, XI(103), 19-20.

Muloud, M. (2015). The Tax Amnesty Program: as Tool to Adjust the Shadow Economy; the International Experience. Global Advance Research Journal, 3(2), 017-025.

Muttaqin, Z. (2013). Tax Amnesty di Indonesia. Bandung: Refika Aditama.

Prawira, I.F. Adi. (2015). The Effect of Granting Tax Amnesty to Tax Revenues, Research Journal of Finance and Accounting, 6(4), 158.

Prasetyo, K. A. (2015). Sunset Policy (lagi): Perlukah? Insidereview, 31(5), 11-14.

Prastowo, Y. (2016). Menimbang Manfaat Kebijakan Tax Amnesty. Jakarta: Center for Indonesia Taxation Analysis.

Ragimun. (2016). Analisis Implementasi Pengampunan Pajak (tax amnesty) di Indonesia. Retrieved from http:www.kemenkeu.go.id.

Rasbin. (2016). Tax Amnesty, Potensi Dana Repatriasi dan Pembangunan di Indonesia, Majalah Info Singkat, VIII (08), 13-16.

\section{Copyrights}

Copyright for this article is retained by the author(s), with first publication rights granted to the journal.

This is an open-access article distributed under the terms and conditions of the Creative Commons Attribution license (http://creativecommons.org/licenses/by/4.0/). 